\title{
MATERIAL ADVERSE CHANGE: AN ALTERNATIVE SOLUTION TO SUSPENSION OF THE DEBT PAYMENT
}

\author{
Suwinto Johan* \\ Management Study, Faculty of Business, President University Jababeka Education Park \\ Jl. Ki Hajar Dewantara, RT. 2/RW. 4, Mekarmukti, North Cikarang, Bekasi 17530, Indonesia \\ Magister Ilmu Hukum, Fakultas Hukum, Universitas Tarumanagara \\ Jl. Letjen S. Parman No. 1 Jakarta 11440, Indonesia \\ suwintojohan@gmail.com
}

Received: $01^{\text {st }}$ August 2020/ Revised: $10^{\text {th }}$ August 2020/ Accepted: $28^{\text {th }}$ September 2020

How to Cite: Johan, S. (2020). Material adverse change: An alternative solution to suspension of the debt payment. Humaniora, 11(3), 211-218. https://doi.org/10.21512/humaniora.v11i3.6606

\begin{abstract}
The research aimed to provide alternative solutions with Material Adverse Change (MAC) before reaching the suspension of the debt payment obligation stage. The pandemic situation had caused many companies to experience difficulties in fulfilling their obligations, including payment obligations or debts to suppliers and creditors. If there were circumstances where the company could not fulfill its obligations, then the creditor would be able to collect through debt-restructuring to bankruptcy. The restructuring was carried out through the suspension of the debt payment obligation (Penundaan Kewajiban Pembayaran Utang/PKPU). The research used normative juridical methods. It focused on credit and financing transactions between companies and creditors, both banking or finance companies. The research concludes that before the suspension of a debt payment obligation, companies and creditors should negotiate based on MAC before reaching a lawsuit. In the MAC, there is an explicit clause, and it is agreed by both parties, then the creditor should acknowledge the company's actual condition.
\end{abstract}

Keywords: material adverse change, restructuring, suspension of debt payment

\section{INTRODUCTION}

In times of crisis, such as the COVID-19 pandemic, many companies experience operational difficulties. This operational difficulty results in financial difficulties. Many companies default or fail in fulfilling their obligations. The COVID-19 pandemic condition has resulted in many businesses becoming unable to operate due to the enactment of Large-Scale Social Restrictions (PSBB). There are only 11 industries are permitted to operate during the Large-Scale Social Restrictions. Besides, community activities also decline, so the demand for products also decreases. As a consequence, total economic activity decreases. With this decline in demand, companies are experiencing difficulties with liquidity and financial distress. The company has difficulty paying debts to suppliers and creditors, so the company defaults.

There is an agreement that allows the related parties to ask for relief concerning the article on force majeure. However, relief depends on the negotiations between the parties following the agreement. Before force majeure, there is a condition called Material Adverse Change (MAC). It is a situation where companies experience performance pressure due to macro factors that change significantly and suddenly. With this, the company can apply what is written on the MAC to take effect.

The MAC clause is different from the Force Majeure clause. Force Majeure is generally in the form of a natural disaster, while MAC is a temporary state of shock, especially on financial variables. Black Thursday and the Great Hanshin Earthquake in 1995 are examples. MAC is not a natural event or a political event at the transaction location or country, but natural events in other countries that give shocks to Indonesia's financial variables. Other examples are the Invasion of Iraq on March 19, 2003, and the Invasion of Kuwait 
Table 1 Definition Force Majeure and Material Adverse Change

\begin{tabular}{|c|c|c|c|c|c|}
\hline No. & Term & Event & Location of Event & Determinant & Example \\
\hline 1. & Force Majeure & $\begin{array}{l}\text { General, natural } \\
\text { event }\end{array}$ & $\begin{array}{l}\text { Location of related } \\
\text { parties }\end{array}$ & Related authority & $\begin{array}{lr}\text { The Great } & \text { Hanshin } \\
\text { earthquake, Aceh } \\
\text { tsunami, COVID-19 } \\
\text { pandemic }\end{array}$ \\
\hline 2. & $\begin{array}{l}\text { Material Adverse } \\
\text { Change or } \\
\text { Material Adverse } \\
\text { Effect }\end{array}$ & $\begin{array}{l}\text { Economic/financial } \\
\text { events / political } \\
\text { events that happen } \\
\text { due to human actions }\end{array}$ & $\begin{array}{l}\text { The location of the } \\
\text { incident can be in } \\
\text { another country, but } \\
\text { it has implications } \\
\text { for the parties } \\
\text { involved in another } \\
\text { location }\end{array}$ & $\begin{array}{l}\text { Parties involved } \\
\text { in the agreement }\end{array}$ & $\begin{array}{l}\text { The September } 11 \\
\text { attack, invasion of } \\
\text { Kuwait, invasion } \\
\text { of Iraq, } 2002 \text { Bali } \\
\text { bombing }\end{array}$ \\
\hline
\end{tabular}

on August 7, 1990. The invasions result in changes in oil prices and affected other financial variables, such as stock indexes, gold, currency exchange rates, and oil prices. These events resulted in several transactions that will experience Material Adverse Change.

Another event experienced by companies in Indonesia is the 2008 global financial crisis. Indonesia does not suffer from a direct effect from the incident, but due to the integration of the global financial markets, several financial indicators have to be changed. These financial indicators are used by the parties to renegotiate the agreement. MAC is a condition or event between the signing of the prerequisite agreement and the transaction settlement. The difference in force majeure and material adverse change is illustrated in Table 1.

Weinsten et al. (2020) have defined MAC provision in credit agreements as a material adverse effect on (1) the business, financial condition, or results of operations of the borrowers and their subsidiaries (taken as a whole); (2) the ability of the credit parties and their subsidiaries (taken as a whole) to perform their payment obligations under the loan documents; or (3) the material rights and remedies (takes as a whole) of the agent and the lenders under the loan documents. According to Threet (2017), regarding the article MAC in merger and acquisition transactions, it is generally done by canceling the transaction if the target company experiences a MAC between a specific date until the transaction completion date. It is reflected in the financial statements that change as the company records.

Before the suspension of debt payment obligation submission, the company has the opportunity to negotiate with creditors if there are indications that MAC would occur. Thus, MAC can provide initial solutions to creditors and debtors to discuss solutions taken before the suspension of the debt payment obligation is submitted to obtain a peace proposal. Damlah (2017) has concluded that Penundaan Kewajiban Pembayaran Utang (PKPU) or the suspension of debt payment obligation aims for peace, including offering full or partial payment of the debt creditors to avoid bankruptcy. It is because debtors are still able to pay them with additional time to improve economic conditions. Zulaeha (2015) has concluded that many companies with the potential to be bankrupt through PKPU. Makmur (2016) has shown that every decision handed down by the judge is not necessarily able to guarantee the truth juridically because the decision is not free from mistakes and errors, and even it is not impossible to be impartial.

In addition, Sari (2017) has found that settlement disputes take the PKPU route because it is considered more beneficial for both parties. Tampemawa (2019) has stated that bankruptcy and postponement of debt payment obligations are the most effective, just, and commendable legal means in settling debts. At the same time, Wijayanta (2014) has stated that the principles of legal certainty, justice, and benefit have been regulated in a balanced manner in the law regarding bankruptcy decisions. In contrast, Rusli (2016) has stated that good faith plays an important role and is more decisive than the state technically insolvent of a company. Kurniawan (2019) has said that bankruptcy is defined as bankruptcy or insolvency. Insolvent is defined as a condition of inability to pay. Surjanto (2018) has concluded that the definition of insolvent in determining whether a company is included in PKPU is not clear. So, it is needed a definition of insolvency. However, Ginting, Firdaus, and Fitriani (2015) have stated that the parties should have enough knowledge about PKPU before applying for a declaration of bankruptcy. In fact, Dewi and Tjatrayasa (2017) have found that with PKPU, there is a suspension of confiscation and execution of guarantees during the PKPU process.

\section{METHODS}

The research uses the empirical juridical method by studying several transactions in Indonesia and other locations connected with Material Adverse Change (MAC). The purpose of studying transactions is to find out the position of the parties in the agreement. The research uses primary data and secondary data. Primary data is material or data obtained directly from the field as the primary source. Primary legal materials, namely binding legal materials, consist of basic norms 
or principles, namely the 1945 Constitution; Laws and regulations; non-codified legal materials, such as customary law and jurisprudence. Secondary material is literature in the form of primary legal materials, secondary legal materials, and tertiary legal materials (Lie et al., 2019).

Data analysis is carried out qualitatively by analyzing a situation or status of phenomena with words or sentences, then separated according to the purpose of the research to conclude. Conclusions are drawn inductively, namely by describing everything in detail and ending with general data or facts. The framework of thinking depicted in Figure 1 shows that the occurrence of essential events resulted in things that hinder the company's activities. With the company's activities being hampered, the company experiences liquidity and financial distress difficulties. With this financial distress, the company experiences a default due to not being able to fulfill obligations that must be fulfilled, such as debt payment due.

With MAC, the company can negotiate with creditors to postpone its obligations before debt restructuring through suspension of debt payment obligation. With MAC, companies can settle liability delays through an out-of-court settlement. The two main theories in this discussion are the theory of bankruptcy and the theory of financial distress.

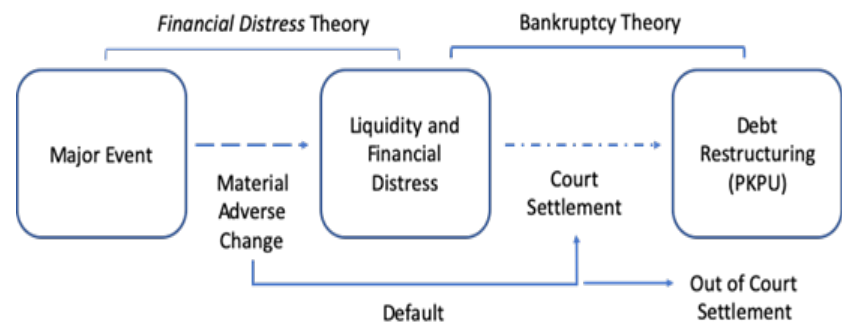

Figure 1 Research Framework

(Source: Research Result)

\section{RESULTS AND DISCUSSIONS}

A country's economy can develop and grow if the financial sector supports it. This function is carried out by financial institutions in the form of bank financial institutions and non-bank financial institutions, such as financing, venture capital, and others. Relations between financial institutions is called systemic effects. Betz et al. (2016) have shown that the banking sector is fragmented and related to banks in countries that are affected by the crisis and how risks arise. Banks and other non-bank financial institutions distribute credit to businesses to drive their business. This loan is to move the economy, such as production, investment, and consumption. Bank financial institutions support national development with the principle of safe and sound in risk management. Fuady (2020) has said that banking follows the principle of prudence in providing loans.
The credit agreement between the bank and the customer is proof of the engagement. Before the credit agreement is signed, the customer must make a credit application and then proceed with data verification. Once examined and approved, the bank will send an offering letter to the customer. If the customer accepts an offer from the bank, then the credit agreement is made. This agreement also agrees on the condition of force majeure. The condition where the debtor has difficulty paying their obligations or the creditor postpones in disbursing their loan facilities.

In addition to difficulties in disbursing funds, there are times when banks experience limitations in determining the interest rates to be charged. This is illustrated in Figures 2 and 3, and there is a lag time between the signing of the loan agreement and the disbursement of funds. During this grace period, it is common because completion of the document, awaiting the original certificate from a notary if the certificate is notarized, registration and delivery of collateral, gradual disbursement of credit in accordance with the requirements of the debtor's request, and the debtor has not fulfilled other requirements.

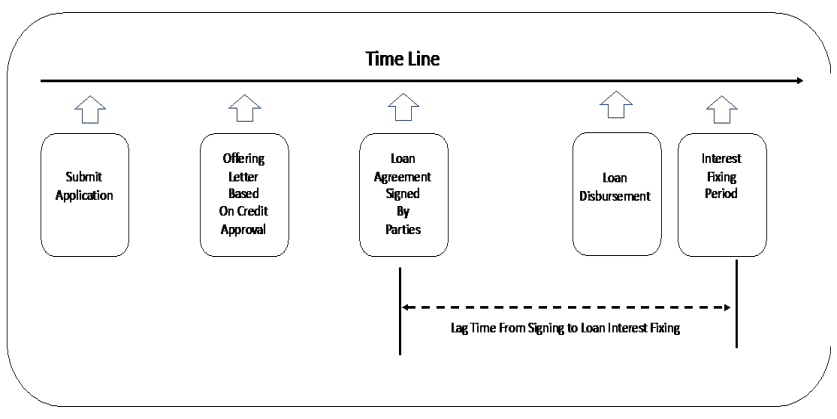

Figure 2 Stages of Bank Credit Disbursement (Source: Research Result)

If something extraordinary happens at this time, the transaction could potentially fail to run. These extraordinary things include natural disasters, pandemics, and events that can significantly affect transactions. It is necessary to arrange in the agreement if things happen that are not normal during this grace period. Article containing these matters is generally referred to as material adverse change.

Financial Service Authority Regulation (Peraturan Otoritas Jasa Keuangan/POJK) number 35 of 2018 article 1 states that finance companies finance customers for the purchase of goods and services. The customer visits the supplier to select the items needed. If the customer wishes to be funded, the prospective customer will submit a financing request, as illustrated in Figure 3. After verification and analysis, approval, then both parties can sign the financing agreement. After the signing, the consumer of the finance company will wait for the invoice from the supplier where the consumer buys the goods. There is a grace period between the binding or signing of the agreement with the disbursement of funding funds. This is caused by the goods that are not available; then the parties must 
wait for the availability of the goods or other technical issues.

During this lag time, there is an unusual event occurring, so funding can be hampered or even canceled. Events such as natural events, pandemics, and policy events can completely change businesses. An agreement is needed if something happens during this grace period.

Besides, the financing agreement imposes fixed installments on the agreement. Thus, there will be a fixed interest. In the financing agreement, there is a clause regarding changes in significant market conditions (MAC). Generally, it is written that if this happens, finance companies are allowed to increase the interest rates charged so that the monthly installment value will change. During the 1998 monetary crisis, Astra Credit Companies (ACC) adjusted the interest rates charged to current consumers due to the current financial condition, which had interest rates close to $60 \%$ per year. Therefore, Astra Credit Companies used the MAC clause to adjust to the interest rates that had been imposed on consumers.

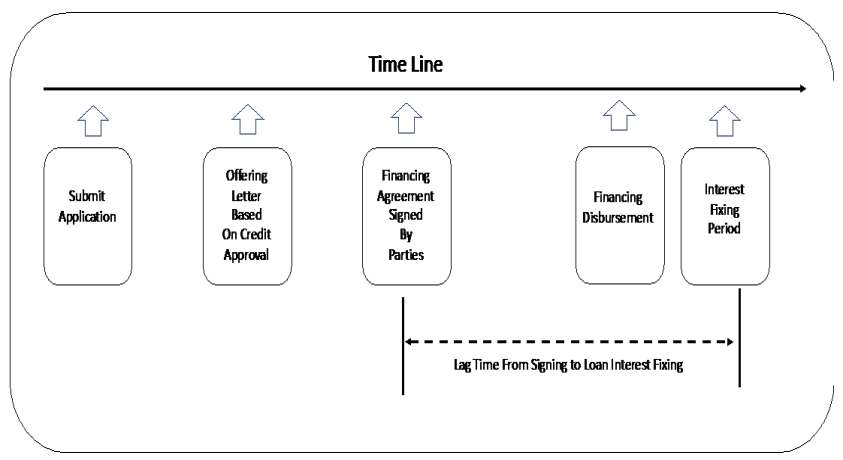

Figure 3 Stages of Financing Companies (Source: Research Result)

An event can result in failure to fulfill the obligation of an agreement such as a natural event, human event, significant change in the economic system, and pandemic. A natural event is caused by nature or caused by an activity from nature, such as a flood, volcanic eruption, typhoon, earthquake, or tsunami. A human event is an event created by government policy, such as moratorium, terrorist attack, civil war, government changes in the form of a specific country's independence, a change in the ruling party, or takeover of power, such as through a coup. At the same time, the pandemic is a condition where a disease has infected several countries and caused deaths at a specific time, according to WHO defines. Some examples of pandemics are COVID-19, Ebola, AIDS, and others. Significant changes happen in the economic order, such as a very drastic change in interest rates, the fall of the stock index, and the occurrence of a banking rush. These things can result in obstruction of a transaction involving finance. Events in the financial industry tend to have systemic risks, where events on one thing will affect other things.
Under normal conditions, monetary policy can affect liquidity in small-sized bank financial institutions. Monetary policy does not directly affect banks during a financial crisis, and banking liquidity trends can predict future crises (Berger \& Bouwman, 2017). The transaction directly affected by the MAC's condition is the loan transaction or financing transaction. This transaction is done in monthly installments. Companies that have installment payment obligations also directly have a liquidity effect. Therefore, this type of transaction will be directly affected by a macro policy. Differences in transactions and pandemic effects are illustrated in Table 2.

Table 2 Types of Material Adverse Change

\begin{tabular}{|c|c|c|}
\hline Events & Type & Effect \\
\hline \multirow[t]{5}{*}{ Natural } & Earthquake & $\begin{array}{l}\text { Delay in the shipment of } \\
\text { goods }\end{array}$ \\
\hline & Flood & $\begin{array}{l}\text { Production facilities are } \\
\text { submerged, so they stop } \\
\text { producing. }\end{array}$ \\
\hline & Typhoon & $\begin{array}{l}\text { Airport closures for } 12 \\
\text { hours, so flights become } \\
\text { hampered. }\end{array}$ \\
\hline & Tsunami & $\begin{array}{l}\text { The tsunami in Palu } \\
\text { Sigi Donggala caused } \\
\text { difficulties in fulfilling } \\
\text { obligations. }\end{array}$ \\
\hline & $\begin{array}{l}\text { Volcanic } \\
\text { Eruption }\end{array}$ & $\begin{array}{l}\text { The eruption of Mount } \\
\text { Merapi resulted in the } \\
\text { Adi Sucipto Airport } \\
\text { being closed for } 24 \\
\text { hours, so tourists need } \\
\text { accommodation and } \\
\text { compensation. }\end{array}$ \\
\hline \multirow[t]{4}{*}{ Human } & $\begin{array}{l}\text { Terrorist } \\
\text { Attack }\end{array}$ & $\begin{array}{l}\text { The American Government } \\
\text { limits the number of } \\
\text { foreign nationals entering } \\
\text { the United States. }\end{array}$ \\
\hline & Protest & $\begin{array}{l}\text { Protesters occupy the } \\
\text { streets for several hours, } \\
\text { sending goods late. }\end{array}$ \\
\hline & Coup & $\begin{array}{l}\text { A coup in a country results } \\
\text { in investors delaying } \\
\text { investment for fear of a } \\
\text { change in policy. }\end{array}$ \\
\hline & $\begin{array}{l}\text { Government } \\
\text { Policy }\end{array}$ & $\begin{array}{l}\text { Foreign exchange } \\
\text { moratorium policy or } \\
\text { nationalization of foreign } \\
\text { assets }\end{array}$ \\
\hline
\end{tabular}

Source: research result

Macroeconomic conditions in the COVID-19 pandemic may have a long or short-term effect. For example, Wuhan, the first city in the COVID-19 
pandemic's emergence, has begun to reactivate its activities. The industry will recover quickly in April 2020. Therefore, the conditions in the MAC must be considered because each event has different implications. Based on the economic conditions that will occur and the conditions of companies and industries experienced, the MAC clause can be run as a result of the pandemic and the economy that occurs. If there is no MAC clause in the agreement, then several variables are directly related to the performance of the macroeconomy, which affects the company that can be used as a benchmark in determining MAC as listed in Table 3. In determining MAC, the variables shown in Table 3 have an impact on the economy, as explained in Table 4.

For credit transactions, both banking and financing, the criteria for using MAC are based on the impact and time of occurrence. If the domicile of one of the parties in the agreement is affected by natural disasters, such as tsunamis, earthquakes, floods, typhoons, volcanic eruptions, then the MAC will be valid for the short to medium term. For events due to human actions, this transaction will follow in accordance with policies set by the legal authority. If transactions involve foreign currencies and a moratorium takes place, then transactions in foreign currencies must be converted into currencies that are in effect for a long period of time.

If the transaction is a moratorium or nationalization, the agreement must adhere to the government policy. Moratoriums include a moratorium on logging, a moratorium on foreign currency, or the nationalization of foreign companies' assets in a country. The MAC must also include a clause regarding compulsory compliance following government regulations. If there is a change in government

Table 3 Variables in Determining MAC

\begin{tabular}{|c|c|c|}
\hline No. & Variable & Explanation \\
\hline 1. & Interest Rate & $\begin{array}{l}\text { Interest rates are monetary policy tools that determine economic } \\
\text { activity. }\end{array}$ \\
\hline 2. & $\begin{array}{l}\text { Exchange Rates against Foreign } \\
\text { Currencies }\end{array}$ & $\begin{array}{l}\text { The exchange rate is an indicator of a country's economy, especially } \\
\text { the balance of payments. }\end{array}$ \\
\hline 3. & Government Policy & Government policies, such as moratorium or nationalization \\
\hline 4. & Composite Stock Price Index & $\begin{array}{l}\text { The composite stock price index is an indicator for investors in an } \\
\text { economy. }\end{array}$ \\
\hline 5. & Inflation & $\begin{array}{l}\text { Inflation reflects the condition of aggregate demand in an economic } \\
\text { system. }\end{array}$ \\
\hline 6. & Commodity Price & $\begin{array}{l}\text { Commodities are industrial raw materials. The increase in } \\
\text { commodity prices will show an economic system. }\end{array}$ \\
\hline 7. & Change in the Legitimate Goverment & $\begin{array}{l}\text { The occurrence of a forced governmental replacement such as a } \\
\text { coup would make investors doubtful of the country situation. }\end{array}$ \\
\hline
\end{tabular}

Source: Research Result from Multiple Sources

Table 4 Material Adverse Change Variable and Type of Transaction

\begin{tabular}{|c|c|c|c|c|}
\hline \multirow{2}{*}{\multicolumn{2}{|c|}{ Type of Transaction }} & \multirow{2}{*}{$\begin{array}{c}\text { Natural Event (Earthquake, Flood, } \\
\text { Eruption, Tsunami) }\end{array}$} & \multirow{2}{*}{\multicolumn{2}{|c|}{ Human Event }} \\
\hline & & & & \\
\hline \multirow[t]{2}{*}{ Loan } & Bank Loan & $\begin{array}{l}\text { Verifying the situation of each different } \\
\text { customer conditions based on the industry }\end{array}$ & Government Policy & Government Policy \\
\hline & Financing & $\begin{array}{l}\text { The condition of the business and } \\
\text { economy, especially interest rates and the } \\
\text { period of business activity may be stalled }\end{array}$ & Government Policy & Government Policy \\
\hline \multirow[t]{2}{*}{$\begin{array}{l}\text { Sales and } \\
\text { Purchase }\end{array}$} & $\begin{array}{l}\text { Land and } \\
\text { Building }\end{array}$ & $\begin{array}{l}\text { If the land is affected by natural disasters, } \\
\text { the transaction is canceled. If not affected, } \\
\text { based on the market price of land and } \\
\text { buildings }\end{array}$ & Government Policy & Government Policy \\
\hline & Company & $\begin{array}{l}\text { Based on economic indicators such as the } \\
\text { market price of shares }\end{array}$ & Government Policy & Government Policy \\
\hline
\end{tabular}

Source: Research Result 
policy, then the fulfillment of the obligations will be renegotiated, or the agreement is determined to be null and void. In addition to events that occur, the type of transaction also affects the article MAC contents to be applied. If the transaction is a debt receivable, then those who have debt or have receivables have different MAC determination criteria. Likewise, for buying and selling transactions, MAC will also differ between positions as sellers and buyers. Besides, the type of transaction will also determine a different MAC, such as buying and selling movable and immovable property.

Sales and purchase transactions may include buying and selling land, buildings, and companies. For land sale and purchase transactions, it will depend on the conditions of natural events. While for the nonnatural events, the transaction is required to follow applicable government regulations. Land sales and purchase transactions may change due to tax changes. In an agreement or contract, the parties determine the criteria that clearly become the MAC benchmark, as explained in Table 5. With this determination, no party can consider MAC's occurrence unilaterally unless the criteria of this are met, which are explained in Table 5.

MAC is also an alternative solution for banking and financing with debtors. If the debtor wants to postpone the installment payment due to occurred conditions, the debtor can use the articles in the agreement. If there is no MAC, then the debtor can submit in two ways; debt restructuring or filling a suspension of debt payment obligation. Debt restructuring will be negotiated with creditors, both banking and financing, and company suppliers. This restructuring takes the form of extending credit terms, reducing installments, lowering interest rates, delaying repayment of payments, and deducting certain debt payments. It can be done without going through a trial because it has been arranged in agreement with the parties.

Filing a suspension of debt payment obligation could through the court. Based on the Law of the Republic of Indonesia number 37 of 2004 on bankruptcy and suspension payment law, the debtor or company may submit suspension of debt payment obligation through the commercial court. The suspension of the debt payment obligation submission process requires 45 days for decisions and a maximum of 270 days to reach a peace proposal or agreement.

Based on the MAC, then the company or debtor should be able to impose a clause in the MAC and direct negotiations between the debtor with banks, financing companies, or suppliers. The criteria for recurrence have met the agreed conditions. If it involves all the creditors, both concurrent and separatist, and through the court, it will require a long time and cost. Swaredheka and Suryandono (2019) have stated that one of the solutions in PKPU settlement is a debt to equity swap, which is converted into shares. Several debt restructuring schemes, as shown in Figure 4.

MAC will provide a more efficient solution for the parties in negotiating the postponement of obligations in debt payments. For those who enter into a debt agreement, it is necessary to write down this MAC condition. The MAC conditions must be obvious and agreed upon by the parties, so different interpretations do not arise. Figure 5 shows the MAC variable criteria.

So far, businesses have always focused on force majeure. However, the MAC condition has become more crucial because force majeure follows the provisions of the government, and the conditions do not allow transactions. At the same time, MAC is a condition where a transaction might be continued but with a delay.

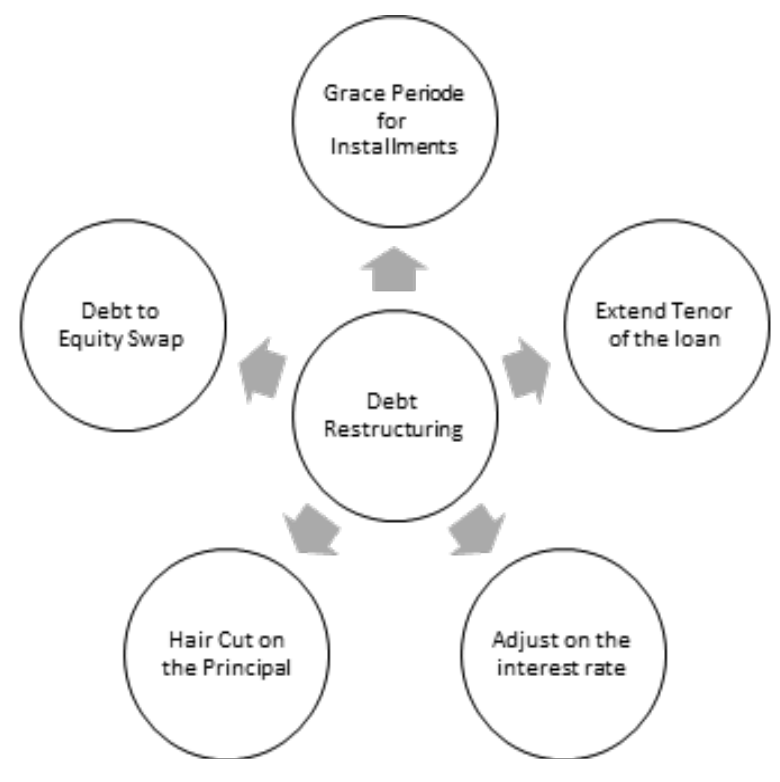

Figure 4 Debt Restructuring Scheme (Source: Research Result) 


\begin{tabular}{|c|c|c|c|c|}
\hline No. & Variable & Criteria & $\begin{array}{l}\text { Sales and Purchase } \\
\text { Transaction }\end{array}$ & $\begin{array}{c}\text { Credit Transaction } \\
\text { (Loan) }\end{array}$ \\
\hline 1. & Interest Rate & $\begin{array}{l}\text { If the interest rate rises significantly to } \mathrm{x} \% \\
\text { or average in a certain percentage over } \\
\text { time, the lender can adjust the interest rate } \\
\text { to } \mathrm{x} \% \text { or both parties can renegotiate. }\end{array}$ & & $\sqrt{ }$ \\
\hline 2. & $\begin{array}{l}\text { Exchange Rates } \\
\text { Against Foreign } \\
\text { Currencies }\end{array}$ & $\begin{array}{l}\text { If the rupiah depreciates or appreciates } \mathrm{x} \% \\
\text { within a specific time. }\end{array}$ & $\begin{array}{l}\sqrt{ } \\
\text { (if the transaction is } \\
\text { in foreign currency) }\end{array}$ & $\begin{array}{l}\sqrt{ } \\
\text { (if the transaction is } \\
\text { in foreign currency) }\end{array}$ \\
\hline 3. & $\begin{array}{l}\text { Government } \\
\text { Policy }\end{array}$ & $\begin{array}{l}\text { If the government carries out specific } \\
\text { policies mentioned in the agreement, } \\
\text { then the transaction can be canceled or } \\
\text { renegotiated. For example, imposing tax } \\
\text { on transactions carried out. }\end{array}$ & $\begin{array}{l}\text { (if the transaction } \\
\text { is related to the } \\
\text { industry's strategy } \\
\text { determined by the } \\
\text { government) }\end{array}$ & $\begin{array}{l}\text { (if the transaction } \\
\text { is related to the } \\
\text { industry's strategy } \\
\text { determined by the } \\
\text { government) }\end{array}$ \\
\hline 4. & $\begin{array}{l}\text { Composite } \\
\text { Stock Price } \\
\text { Index or Stock } \\
\text { Price }\end{array}$ & $\begin{array}{l}\text { If the Stock Price Index decreases or } \\
\text { increases by } \mathrm{x} \% \text { within a specific period, } \\
\text { the transaction will be reviewed. }\end{array}$ & $\begin{array}{l}\text { (Generally, if the } \\
\text { transaction is related } \\
\text { to publicly listed } \\
\text { company shares) }\end{array}$ & \\
\hline 5. & Inflation & $\begin{array}{l}\text { If monthly or accumulated inflation } \\
\text { reaches } \mathrm{x} \% \text { within a specific period, } \\
\text { then the transaction can be cancelled or } \\
\text { renegotiated. }\end{array}$ & & $\sqrt{ }$ \\
\hline 6. & $\begin{array}{l}\text { Commodity } \\
\text { Price }\end{array}$ & $\begin{array}{l}\text { If the commodity prices associated with } \\
\text { the transaction increase or decrease by } \mathrm{x} \% \\
\text { or a specific value, then the transaction can } \\
\text { be cancelled or renegotiated. }\end{array}$ & $\begin{array}{l}\quad \sqrt{ } \\
\text { (If the industry is } \\
\text { associated with } \\
\text { several commodity } \\
\text { prices) }\end{array}$ & \\
\hline
\end{tabular}

Note: $\sqrt{ }=$ generally applied and involved

Source: Research Result from Multiple Sources

\section{CONCLUSIONS}

There are several transactions in industries that have already declared Material Adverse Change (MAC). However, a more in-depth analysis of the MAC definition is needed. The industry is directly affected to announce the MAC and the implications of the period for this event. The determination of the MAC is long-term, or only short-term needs to be agreed upon. In the case of the COVID-19 pandemic, the parties also need to agree on variables and criteria when the MAC occurs. This agreement is in line with the principle of freedom of contract, where the parties fulfill the requirements to agree on the contracts. For business, they must also fulfill the principle of balance and agreement to determine MAC contents.

Agreement in the contract regarding the MAC becomes crucial before the event happens. If there is no clear definition of MAC, then it will not be easy to be enforced. Both parties must agree in determining the criteria and definition of the MAC. MAC is also a part of the company's risk management in anticipation of events beyond its ability to control. The determination of this MAC becomes essential and must be clear so that the parties do not accuse each other at the time of enactment. The determination of this MAC considers the conditions and consequences in related industries. MAC determination must be clear about the criteria that can be used. Business intending to enter into an agreement or contract must agree on the determination of the MAC definition. The variables are considered triggers for the MAC and the criteria by which the MAC can occur and be enforced more critically before the business can use force majeure.

For academics, further research relating to other types of agreements on buying and selling companies and banking/financing loans, and other exceptional conditions become an interesting research topic to be investigated in the future. Besides, it is necessary to include other variables, besides economic and political variables in determining MAC.

\section{REFERENCES}

Berger, A. N., \& Bouwman, C. H. S. (2017). Bank liquidity creation, monetary policy, and financial crises. Journal of Financial Stability, 30, 139-155. https:// doi.org/10.1016/j.jfs.2017.05.001. 
Betz, F., Hautsch, N., Peltonen, T. A., \& Schienle, M. (2016). Systemic risk spillovers in the European banking and sovereign network. Journal of Financial Stability, 25, 206-224. https://doi.org/10.1016/j. jfs.2015.10.006.

Damlah, J. (2017). Akibat hukum putusan kepailitan dan penundaan kewajiban pembayaran utang berdasarkan Undang-Undang no. 37 tahun 2004. Lex Crimen, 6(2), 91-98.

Dewi, W. W., \& Tjatrayasa, I. M. (2017). Akibat hukum penundaan kewajiban pembayaran utang terhadap status sita dan eksekusi jaminan ditinjau dari Undang-Undang nomor 37 tahun 2014. Kertha Semaya: Jurnal Ilmu Hukum, 5(1), 1-6.

Fuady, M. (2020). Bahan kuliah Hukum Perbankan. Jakarta: Universitas Tarumanagara.

Ginting, V. R., Firdaus., \& Fitriani, R. (2015). Analisis terhadap penolakan perdamaian pada penundaan kewajiban pembayaran utang (PKPU) oleh kreditur separatis dalam perkara kepailitan. Jurnal Online Mahasiswa Fakultas Hukum Universitas Riau, 2(1), $1-15$.

Kurniawan, H. (2019). Penundaan kewajiban pembayaran utang pada kepailitan melalui perdamaian. Jurnal Ilmiah Focus Mahasiswa UPMI, 1(1), 53-65.

Lie, G., Saly, J. N., Gunadi, A., \& Tiray, A. M. (2019). Problematik UU no. 37 tahun 2004 tentang kepailitan dan PKPU terhadap bank sebagai kreditor separatis. Jurnal Bakti Masyarakat Indonesia, 2(2), 159-168. http://dx.doi.org/10.24912/jbmi.v2i2.7242.

Makmur, S. (2016). Kepastian hukum kepailitan bagi kreditur dan debitur pada Pengadilan Niaga Indonesia. Mizan; Jurnal Ilmu Syariah, 4(2), $337-$ 368.

Rusli, T. (2016). Analisis terhadap penyehatan perusahaan melalui PKPU yang berkeadilan. Jurnal Keadilan Progresif, 7(2), 91-104.

Sari, A. (2017). Penundaaan kewajiban pembayaran utang menurut undang-undang kepailitan. Kajian Ilmiah, 17(2), 51-62. https://dx.doi.org/10.31599/jki. v17i2.79.
Surjanto, D. (2018). Urgensi pengaturan syarat insolvensi dalam undang-undang kepailitan dan penundaan kewajiban pembayaran utang. Acta Comitas Jurnal Hukum Kenotariatan, 3(2), 258-268. https://doi. org/10.24843/AC.2018.v03.i02.p03.

Swaradheka, S. A., \& Suryandono, W. (2019). Kepastian hukum atas pelaksanaan debt to equity swap terhadap obligasi yang dikonversi menjadi saham dalam rangka penundaan kewajiban pembayaran utang. Indonesian Notary, 1(2), 1-21.

Tampemawa, S. G. (2019). Prosedur dan tatacara penundaan kewajiban pembayaran utang menurut UndangUndang no. 37 tahun 2004 tentang kepailitan dan penundaan kewajiban pembayaran utang. Lex Privatum, 7(6), 5-11.

Threet, H. C. (2017). The definition of Material Adverse Change: Balancing risk in merger agreements under Delaware Law. Transactions: The Tennessee Journal of Business Law, 18, 1007-1028.

Weinstein, G., de Wied, W., Kagan, S., Fried., Frank., Harris., Shiver., \& Jacobson, L. L. P. (2020). COVID-19 as a Material Adverse Effect (MAC) under $M \& A$ and financing agreements. Retrieved on April 17 $7^{\text {th }}, 2020$ from https://corpgov.law.harvard. edu/2020/04/04/COVID-19-as-a-material-adverseeffect-mac-under-ma-and-financing-agreements/.

Wijayanta, T. (2014). Asas kepastian hukum, keadilan dan kemanfaatan dalam kaitannya dengan putusan kepailitan pengadilan niaga. Jurnal Dinamika Hukum, 14(2), 216-226. http://dx.doi. org/10.20884/1.jdh.2014.14.2.291.

Zulaeha, M. (2015). Mengevaluasi pembuktian sederhana dalam kepailitan sebagai perlindungan terhadap dunia usaha di Indonesia. Adapher: Jurnal Hukum Acara Perdata, 1(2), 171-187. https://doi. org/10.36913/jhaper.v1i2.18. 